\title{
HOW CAN "GENDER PLANNING" CONTRIBUTE TO TACKLE THE CHALLENGES OF DEMOGRAPHIC CHANGE?
}

\author{
Heidrun Wankiewicz ${ }^{1}$
}

Received 15 November 2012; Accepted 13 December 2013

\begin{abstract}
Ageing society, lack of skilled workforce, changes in work life careers and changes in partner and family models, a shift in societal roles of women and men, young and old, migration flows from rural to urban, multiple residences and new forms of housing and the related spatial impacts are in focus of demographic change. It is obvious that demographic change is not to be managed without gender and equality issues. Spatial planning has a crucial role in facing these challenges as spatial planning laws demand to ensure equal access to housing, services and labour markets and to organize transparent and inclusive decision making procedures. The paper explores key concepts, methods and selected case studies from Europe on gender planning trying to focus on the potential for innovating planning discipline and tackling with demographic change issues in rural areas. Cases from Bavaria and Austria compared to rural regions in Eastern Germany with high female emigration show concrete planning approaches.
\end{abstract}

Keywords: planning for the everyday, gendered distribution of work, spatial living conditions of women and men in rural areas, spatial impacts of demographic change, supportive infrastructures, participation

Zusammenfassung: Analysiert man die Phänomene des demographischen Wandels, wie alternde Gesellschaft, Landflucht, Fachkräftemangel, neue Wohnformen, geänderte Arbeitsbiographien, neue Familien und Partnerschaftsmodell, Veränderungen der Männer- und Frauenrollen - so wird klar, dass die Analyse der Auswirkungen dieses Wandels auf räumliche Strukturen und Lebensbedingungen nicht ohne Einbeziehung von Genderfragen auskommt. Der Raumordnung und Raumplanung kommt bei diesem Umgang eine Schlüsselrolle zu, hat sie doch den Auftrag Alltagstaugliche Infrastrukturen, d.h. Zugang zu Wohnungen, Arbeitsplätzen und Dienstleistungen zu sichern. Das Paper untersucht die Gender Planning Schlüsselkonzepte und Methoden im Hinblick auf deren möglichen Beitrag zum Umgang mit dem demographischen Wandel im ländlichen Raum. Fallbeispiele aus Österreich und Bayern im Vergleich mit ostdeutschen Ländern mit hoher selektiver Abwanderung von Frauen zeigen konkrete Planungsansätze auf.

\footnotetext{
${ }^{1}$ Independent research professional and consulting engineer at studio planwind.at, Bergheimer Straße 42,5010 Salzburg, Austria; e-mail: wankiewicz@planwind.at
} 
Schlüsselwörter: Alltastaugliche Räume, räumliche Lebensbedingungen von Frauen und Männern im ländlichen Raum, räumliche Wirkung des demographischen Wandels, geschlechtsspezifische Arbeitsteilung, Versorgungsinfrastruktur

\section{Introduction}

Ageing society, lack of skilled workforce, changes in work life careers and changes in partner and family models, a shift in societal roles of women and men, young and old migration flows from rural to urban, multiple residences and new forms of housing, as well as the related spatial impacts are in focus of demographic change (Egerö 2012, Zibell 2006, Labit 2012, Demochange 2013). To mention only few of the effects of these trends: higher life expectancy of women as well as selected emigration of young women from rural areas to urban agglomerations leads to considerable surplus of one sex in different age cohorts. On top of the agenda of many rural regions is the challenge to reduce out-migration and keep more young people in the region; in many of these regions, selective migration flows of young women between 18 and 29 can be observed (SEMIGRA 2013, Demochange 2011a,b, Grontmij et al. 2011, Berlin Institute 2009). Further, growing female participation in the labour market - parttime or full-time, commuting for work and qualification, single parenthood and patchwork families ask for new and flexible care and mobility infrastructures in cities and in rural areas. These are big challenges for shrinking communities, as centralization in public and private services and strong cuts in public budgets make it difficult, to provide required infrastructures for daily life and keep quality of life in these communities.

Taking into account these trends and challenges, it is obvious that planning with demographic change is not to be managed without gender and equality issues. Spatial planning has a crucial role in facing these challenges: spatial planning laws demand to provide equal living conditions for all, to combat spatial and social disparities, to ensure equal access to housing, services and labour markets and finally, to organize transparent and inclusive decision making procedures (Fainstein 2009, Dollinger et. al 2010, Larsson 2006, Wankiewicz 2009). Local and regional governments have the legal power for town and country planning, land use plan and building permits, housing and transportation issues, child-care and health care. Furthermore, they coordinate and implement sector policies from state level. So they are the key players for optimizing the spatial living conditions of their citizens. Additionally they assign the level of participation of decision making. However, the impact of neglecting gender and diversity aspects in spatial planning are still underestimated by planners, regional developers and local policy makers. Although there are manifold gendered patterns in the use of space planning, policies tend to ignore these different time-space patters, which cause dysfunction of communities and inaccessible infrastructure for some groups: The 9 - 5 fulltime breadwinner model is still common in the heads of planning professionals and decision makers, the peakhour orientation of public transport schedules, the opening hours of child-care facilities still reflect this breadwinner concept. (cf. Burgess 2008, Cortolezis 2010, Greed 2007, Tummers 2010).

To illustrate the importance of gender planning approaches for rural areas in the field of labour market and location development, I refer to Austrian business park development, innovation strategies and location development of rural areas, which - in general - are gender-blind: Technology parks, IT-centres, business incubators and industrial developments in rural areas do not include gender planning strategies, so they provide work places for technically oriented mostly male workforce, as the job market in Austria is still very segregated - almost $67 \%$ of women work in 'typically female jobs', like hairdresser, shop assistant and office assistant. Two Austrian projects linked to business park development (Lower Austria) and to regional technology and innovation centres (Styria) show the potential of a gender equality oriented location development and management of these industrial zones. (Land Niederösterreich 2007, Aufhauser 2005). These gendered approaches for business park and location development are gaining importance in rural areas: Due to demographic change in age groups, some regions have already been facing strong lack of skilled work-force and are starting campaigns now to enlist young women for technical and scientific jobs. 
Beyond these thematic links, we are integrating gender issues into our conceptualization of demographic change applying the extended concept of demographic change, which was proposed in 2005 by a group of German researchers. Thus, demographic change comprises not only all changes in population due to ageing, shrinking fertility rates, migration but also social change initiated by feminist movements, gender equality and women's liberation, social change in new family models and lifestyles, social change due to new technologies and due to new mobility patterns, finally the growing disparities between social groups (cf. ZGB 2005, 2)

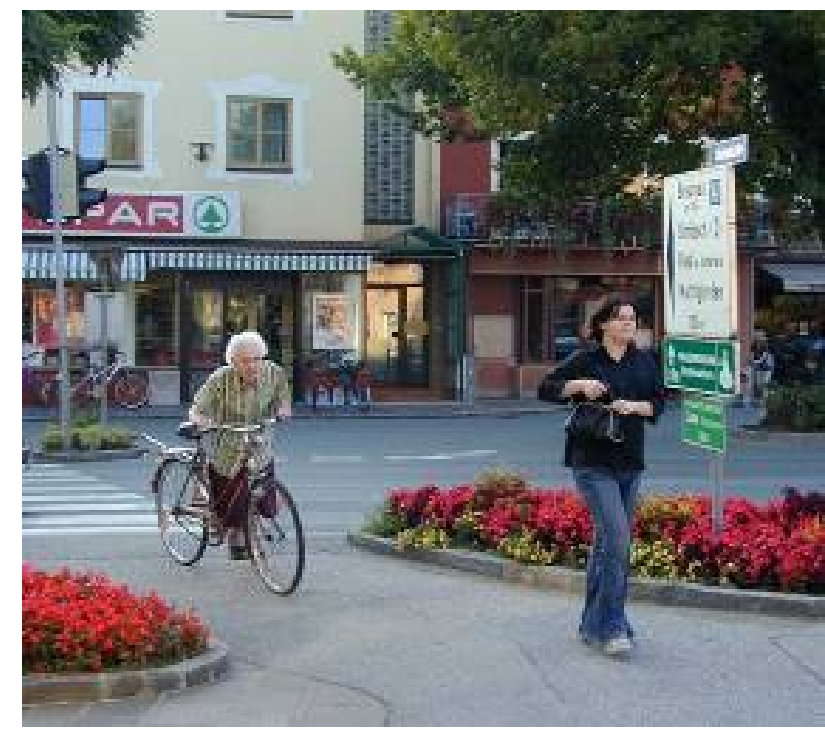

Fig 1. Planning for all ages, planning for the everyday Life (picture planwind.at).

This paper argues that gender planning instruments and concepts can contribute substantially to deliver better spatial planning and development policies, which tackle the impact of demographic change. 15 years after the EU-Treaty of Amsterdam², which has put gender equality and gender mainstreaming on top of the European agenda, it is high time to rethink spatial planning and regional development with a gendered lens.

The paper starts by presenting selected concepts and policy strategies, namely the gender mainstreaming strategy to be implemented in all fields of policy making and planning. Then, the introduction of this gender mainstreaming strategy into the planning cycle tries to give a first answer to the question, what gender mainstreaming in planning means. Next, the key concept of "everyday life" (Horelli 2010, Sustaining Everyday Life 2010) is introduced and described the implications for gender planning, the link to demographic change dynamics and its impacts on rural areas in stagnating and shrinking rural regions. Chapter 2 puts a gendered lens and a gender planning approach for better understanding and tackling main challenges for shrinking or stagnating rural areas which are selective female emigration, labour market and work, infrastructure of everyday life and participation and illustrates this with cases from Bavaria, Austria and regions from Eastern Germany, which suffer the strongest female emigration of Europe. Chapter 3 presents three concrete examples from Austria and Bavaria by looking closer to the applied gender planning methods, tools and strategies in the above mentioned three key issues, namely work, infrastructures for everyday life and participation in decision making. Conclusions summarize the main findings of the paper.

\section{Gender Planning - Gender Mainstreaming in Planning}

Gender planning' has not had a single theory, but manifold concepts, methods and successful practices since the $19^{\text {th }}$ century. Since the eighties of the $20^{\text {th }}$ century, scholars have intensified research on history, concepts and concrete examples and there is a growing body of knowledge on the topic. The variety of issues is illustrated in Figure 2.

\footnotetext{
${ }^{2}$ Treaty of Amsterdam signed 2nd of Oct 1997, entered into force on 1st of May 1999 has been ratified by all member states and became mandatory for all public authorities from local scale and regional scale to EU-scale.
} 


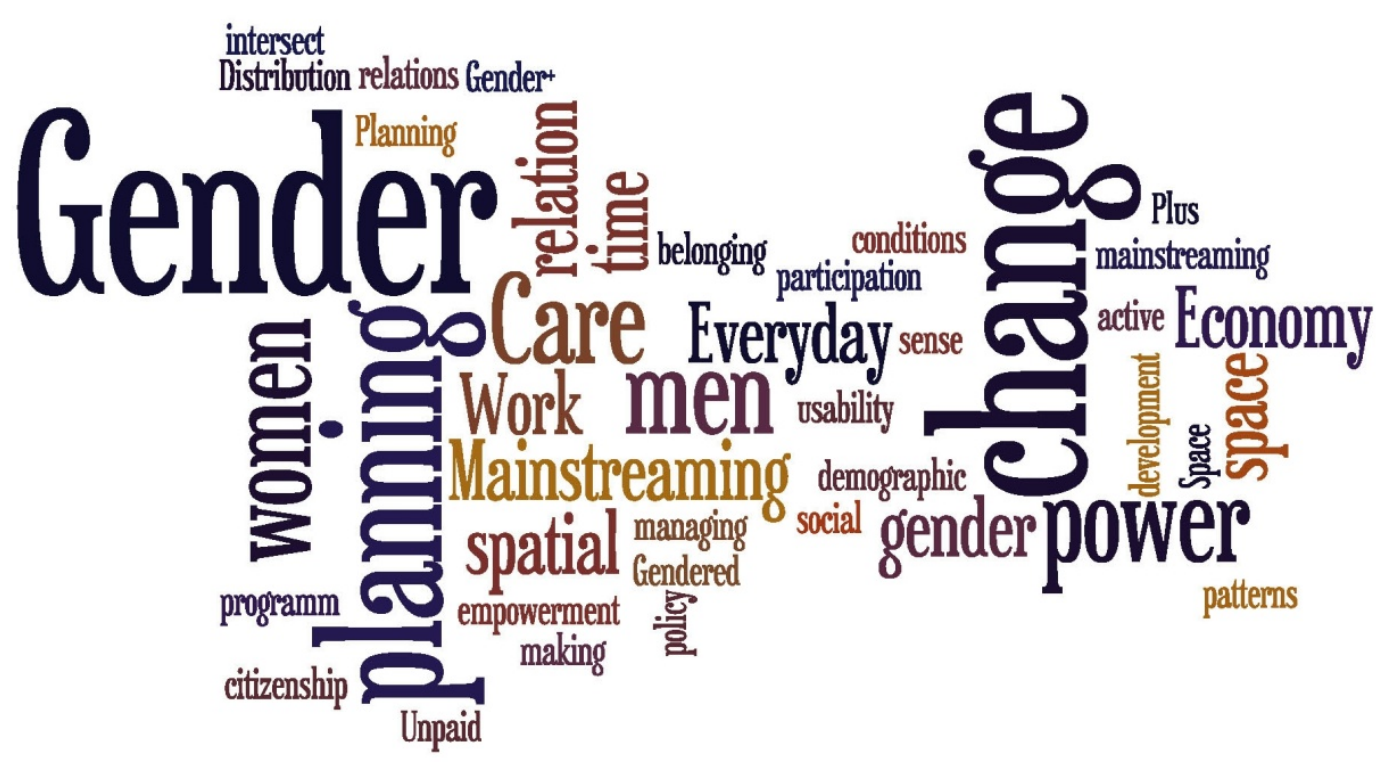

Fig 2. Key concepts and terminology in theorizing gender planning (Wankiewicz).

For this paper, the author is building on the state of the art discussion and the cooperation with the European network on Gender and Diversity in Spatial Planning, called GDUS ${ }^{3}$. Among other goals, GDUS aims to share and systematize European experiences and to theorize gender planning in conferences and projects; the last one taking place in Hannover in April 2012 (genderarchland \& GDUS 2013) and in a book publication 'Fair Shared Cities. The impact of Gender Planning in Europe' (Sanchez de Madariaga \& Roberts 2013). The introduction gives a comprehensive overview on the history, the ongoing debates, differences and open questions on 'gender planning' and 'gendering spatial planning' (Roberts 2013).

\subsection{Gender Planning - a pragmatic approach}

For the paper, as for practical work, we use a pragmatic approach of gender planning, which has been proposed by Damyanovic. She proposes four planning principles and working steps in a planning cycle for a gender planning approach. According to her definition gender planning ...

1. places women and men and their relation to each other in the centre of interest,

2. analyses and evaluates spatial structures according to their usability in everyday life for women and men by including age, differences in stage of life and in cultural and social background into this evaluation,

3. makes visible and deconstructs power relations, social conditions and assessment behind planning concepts,

4. aims to transform and change spatial living conditions and planning concepts towards more equality between women and men (Damyanovic 2007).

Additionally: number 5. Gender planning has to be participatory and gives a voice and the possibility to the weaker groups in society to shape the future of their community and region (Zibell 2006, Hudson \& Rönnblom 2008).

Next chapter presents shortly the underlying concepts and policy strategies including the legal basis of the gender mainstreaming strategy from this pragmatic approach, like gender, everyday life, gendering spatial planning and the transformative potential of gender planning.

\subsection{Embedding into legal framework at EU-level}

Gender planning is building on European values which are 'the indivisible, universal values of human dignity, freedom, equality and solidarity' (CEC 2010: 1), which demand equal treatment

\footnotetext{
${ }^{3}$ GDUS - www.rali.boku.ac.at/gdus.html
} 
of every individual based on democracy and citizenship. In 1997, with the Treaty of Amsterdam, the European Union has renewed the duty of all member states and policy fields to promote equality between women and men and to combat discrimination based on sex, racial or ethnic origin, religion or belief, disability, age or sexual orientation. With this Treaty, the gender mainstreaming strategy as horizontal strategy has become mandatory to all policy fields in order to promote and to achieve gender equality in all EU member states for national, regional and local policies. Since then, all public authorities, from local to national and European have had to combat discrimination and have had to promote gender equality. This also means that all European policies, programmes and all EU funded projects in regional development have to follow a gender mainstreaming strategy: The Council Decision of the EU on Community strategic guidelines on cohesion policy for the ongoing programming period 2007 - 2013 stipulates the following:

,In the context of its effort in favour of economic and social cohesion, the Community, at all stages of implementation of the Funds, has as its goals the elimination of inequality and the promotion of equality between men and women, as enshrined in Articles 2 and 3 of the Treaty, as well as combating discrimination based on sex, racial or ethnic origin, religion or belief, disability, age or sexual orientation'. (CEC 2006, 2)

\subsection{Concepts and definitions}

Gender - Space - Spatial Planning

'Gender' is seen as a dynamic category of socially constructed notions about appropriate roles and behaviours for women and men. As these notions are socially constructed, they can be deconstructed and therefore they can be changed. (Fainstein \& Servon, 2005, 3).

How gender is inscribed into space? Since the eighties it has been widely discussed and in the end entered mainstream planning that built environment and spatial structures reflect the social order and - by this - also reflect the gender and power relations between women and men. So, we assume that space is socially produced and can therefore be socially changed, and the spatial shapes the social and the social shapes the spatial (Lefebvre 1991, Löw 2001, Massey 1994, Soja 2009, 33,). This has consequences for spatial planning theory and practice.

Space defines what people can do, how people interact and feel about themselves and their communities. Planning is about creating better spaces and places. Spatial planning involves understanding and responding to how people in different equality categories use, experience, and feel about places and spaces. It should seek as far as possible to eliminate inequalities that are due to differential use, experience or perceptions about places and spaces (RTPI 2007, 4)

\section{'Everyday life' - putting 'care' and domestic chores on the spatial agenda}

As has been highlighted, the perspective of everyday life is seen as an important concept for considering gender relations and gender roles in spatial planning and for evaluating the quality and usability of the built environment. Many of the concrete examples in the following chapter are referring to the everyday life perspective and the required infrastructures.

'Everyday life' refers to the subjective experience of everyday (de Certeau 1984) it can be seen as the practices and process of people in domestic work, care of children and elderly, shopping, cleaning, transport to work etc. (Horelli 2013). By this, it puts care work on the spatial agenda. Mastering the sustaining of everyday life is a relevant strategy for gender planning but can also be transferred to all groups of society, like elderly, new residents etc. Spatial Planning could be understood as a set of instruments, tools and procedures to manage the everyday lives of people and by this supports equal living conditions of ALL (Dollinger et al 2010, 601).

The concept has been formulated in the seventies in Scandinavia as a vision and practice called "The New Everyday Life“, initiated from the Nordic Women's movement aiming to improve the quality of infrastructure and housing in order to make everyday life and daily 
routines easier (Sustaining Everyday Life 2010). The everyday life approach can be seen as an enhancing approach, eg. development and shape of a supportive infrastructure of everyday life aiming at alleviating daily routines and care work (mostly done by women). It also can be a transformative approach, aiming to change the gendered roles, to redistribute care economy between women and men (Horelli 2013, more in next chapter).

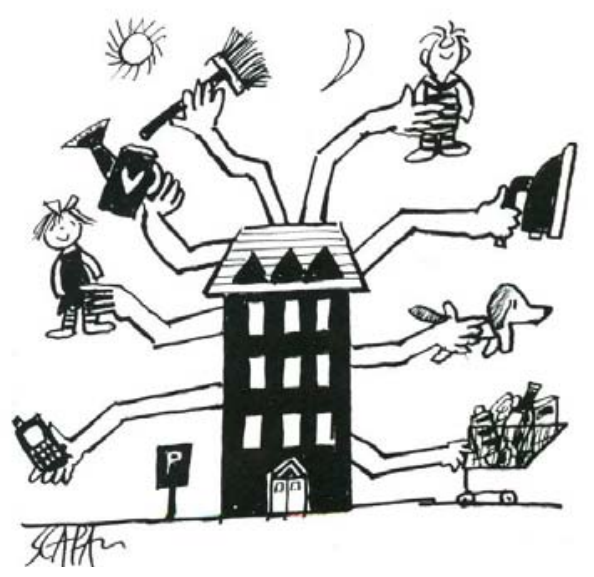

In Austria, the concept of "everyday life" as a gender planning task was introduced officially in the city of Vienna in 1998, when a planning and gender equality unit was established, the so called 'Co-ordination Office for Planning and Construction, Geared to the Requirements of Daily Life and the Specific Needs of Women" (Kail and Irschek 2012). From there the concept and the Gender Panning task has found few echoes in other cities (Innsbruck, Graz) and in rural areas of Lower and Upper Austria, in Salzburg, Styria and in Carinthia eg. Land Salzburg 2007a, Land Niederösterreich 2007 and Aufhauser 2005.

Fig 3. Housing and the everyday life (Illustration by Ted Scapa in Häberli et al 1991).

\section{Conserving or transforming gender roles in gender planning?}

It is important to highlight the tensions between 'women friendly planning' and 'gender planning':

Women friendly planning aims at the improvement of women's everyday life without trying to change 'traditionally gendered' roles, which in some rural areas have persisted (see below Grontmij et al 2011).

Gender planning on the other hand 'looks at structural inequalities and aims at the deconstruction of the social roles of women and men in spatial terms. Instead of confirming women's nurturing role in society a gendered approach combats structural inequalities and aims at the deconstruction of the social roles of women and men in spatial terms. Instead of confirming the 'male breadwinner-female-caregiver' (Aufhauser 2003, 1) stereotyping role models, a gendered approach helps to unpack the assumptions and values underlying planning theory and planning (Fainstein \& Servon 2005, 3). A gendered approach seeks to provide spatial patterns and infrastructures, which enhance the choice for women and men in their societal roles as breadwinners, house-keepers, politicians, grass-root activists etc. (Tummers \& Wankiewicz 2009, 6).

To give an example, which may challenge the traditional concept for public social infrastructure, e.g. the location of child-care facilities and the debate, if these facilities should be situated near working places, or in residential areas is an important gender planning issue. In practice they are situated near working places of women. Although being meant to make life easier for mothers at the same time confirms women's role as being responsible for care tasks. A gendered planning approach would discuss about mixed use and suitable scales and networks for child care facilities in the urban and rural tissues, in order to allow choice for both women and men to share care responsibilities in their daily routines.

\section{Deconstructing planning principles and underlying values}

One important step in gender planning is to reflect the underlying assumptions behind planning principles. For example the gender- and age-blind concept of 'dormitory villages' which only sees full-time workers leaving a village in the morning. This planning concept neglects the much bigger group of inhabitants of a village / quarter like children, senior citizens and part time working people or people working in care (household, care for elderly etc.), women and men, girls and boys who live and work in the village all day long.

\footnotetext{
${ }^{4}$ Official translation of the office called 'Stelle für Alltagsgerechtes Bauen und Wohnen" in City of Vienna.
} 
Another example: If housing is seen through a gender lens, the concept of housing has to be extended: The house is not only the shelter, the physical environment for being protected against rain and weather. The house is also the place of care work and the place of recreation, the place where reproductive work takes place. So the location of the house - how close are services of proximity and supply, how good are mobility offers etc. - is relevant for sustaining everyday life. Finally, the house is the place of integration like growing up into a family, into a neighbourhood and into a village or city quarter. This extension is not only relevant for gender planning, it can be easily applied to migrants, to patchwork families, to new partnerships (Zibell 2006, 8).

\subsection{Methodology -gender mainstreaming a spatial planning cycle}

Mainstreaming gender in spatial planning can be defined as the integration of the gender perspective into the different stages of the planning cycle. Horelli already has opened the issue to age and cultural context saying that gender mainstreaming can be defined as 'the application of a set of gender, age and culture-sensitive visions, concepts, strategies, and practices in the different phases and arenas of the planning and development cycle (Horelli 2009, 6). This definition includes the differences and specific cultural settings, values and living arrangements in different rural areas - from small agricultural villages in the Alps to villages with more or less urban cultures in touristic areas (skiing resorts, festival and spa resorts etc.).

Figure 12 illustrates an ideal planning cycle which has to be gendered. Starting with the initiation and project design, spatial and social analysis, creating visions and defining goals and targets, planning and design - the core task of planning, implementation and maintenance, not to forget evaluation and restart with the next cycle. The gender lens - as defined above has to be applied at all these steps of the planning cycle ${ }^{5}$. All 'gender' issues can be extended with the issues linked to demographic change, like age, cultural or migrant background etc.

The examples in chapters 2 and 3 have been chosen according to selected steps of the planning cycle and concrete practical application of gender planning approaches.

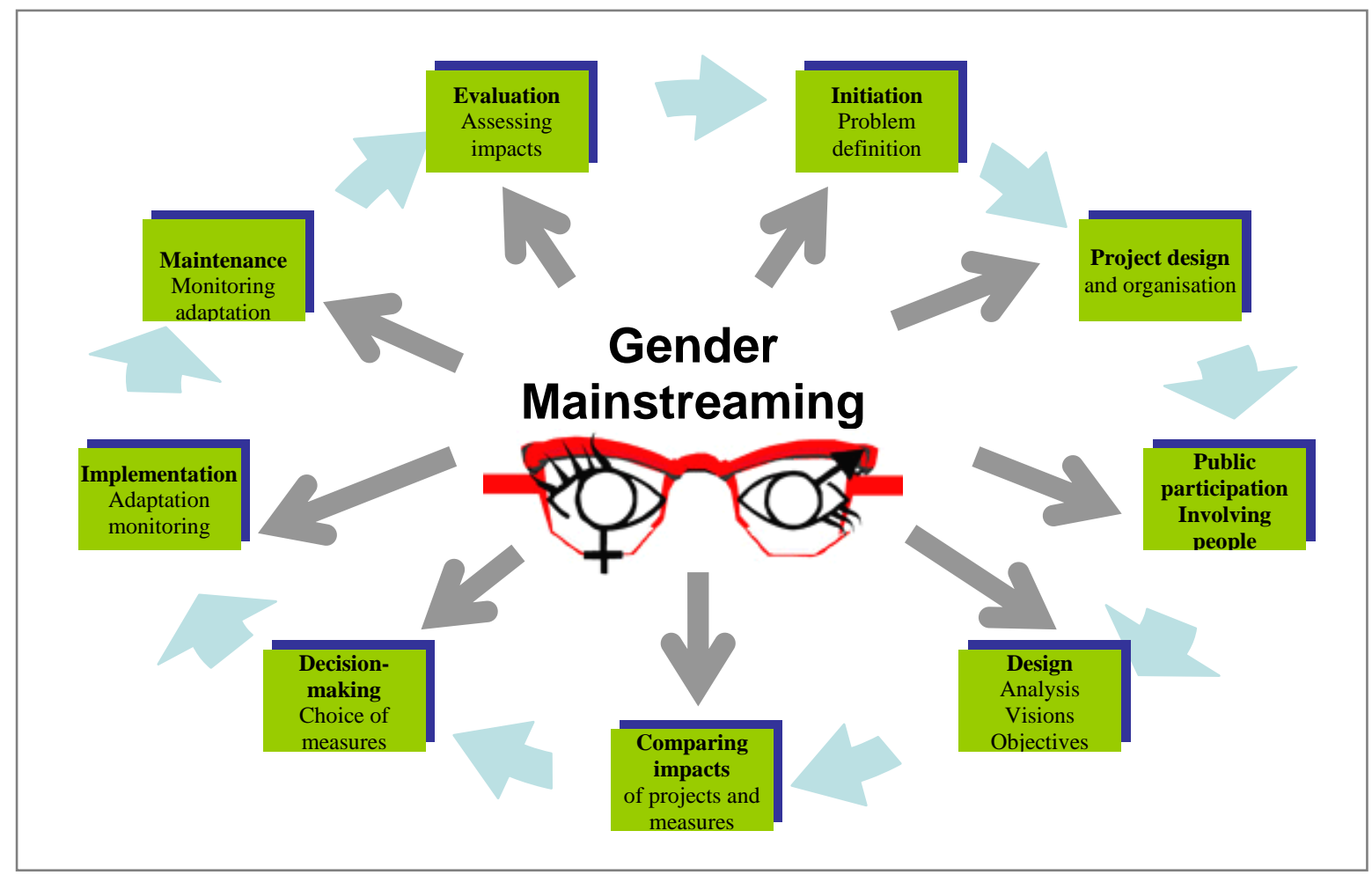

Fig 4. Gender mainstreaming in all steps of a planning cycle.

\footnotetext{
${ }^{5}$ For detailed research on gender mainstreaming in planning and administration see Wotha 2000.
} 
Participation: Start of gender-fair/age-fair/migrant-fair etc. participation process at an early stage (analysis/problem definition);

Methods: target group-oriented timescale \& communication including visualisation of concepts and plans in comprehensive models (including different generations, migrant backgrounds and their position in lifecycle. Giving voice to those who are not generally heard (advocacy planning). Especially challenging in rural areas as political representation of women is rare

Comparing Impacts of different plans: Guiding questions could be: 'Have the issues of all groups of users been taken into account? Does the design/concept take into account the requirements of everyday use?

Methods: 'Usability' check, feedback from different disciplines, testing, Ex-ante Evaluation, Gender Impact Assessment, Health Impact Assessment, etc.

Decision-making / Choice of measures / Public consultation: Who decides? Members of city boards/councils (women/men), citizens (women/men - gender+)?

Methods: wide range of events and workshops, encouraging offers to participate in decision-making and bringing in the point of view of diverse users. Systematic rules of procedures to integrate the voice of NGOs/ user groups. With a great potential in rural areas to involve women and girls as well as a great number of (formal) associations and informal neighbourhood networks.

Implementation and necessary adaptation of the project's objectives and measures: Guiding questions could be: Is the implementation consistent with the planning objectives? Are there deviations/ changes which jeopardize gender-fair (generation-fair, locals and new residents, deprived etc.) issues? Are adaptations necessary due to a time-lag between planning and implementation?

Tab 1. Selected steps of the planning cycle (issues linked to demographic change and special interest for rural areas in red).

In the next chapter the above mentioned concepts and methods are applied and explained in planning processes in rural regions and communities from Austria and Bavaria, by focusing on four main challenges: Selective emigration and imbalanced sex ration in age groups, planning within the structural framework of labour market and work by including care work, as well as planning, regarding the required infrastructures for everyday life.

\section{A Gendered Lens on Four Key Challenges for Rural Areas}

As mentioned before, the focus of the paper is on rural areas with stagnation or loss of population due to emigration and decline of birth rates. One of the main challenges of these regions is to manage stagnation or loss of population and considerable changes in age and social structure and to maintain the quality of life of their inhabitants by adapting and maintaining local and regional infrastructures for everyday life and offering working opportunities for their inhabitants.

The following chapter tries to demonstrate the relevance of a gendered lens and a gender planning approach for better understanding and tackling key challenges:

As has been researched Europe wide by the ESPON project SEMIGRA ${ }^{6}$, migration patterns of young women and men vary considerably according to the regional context, which includes job offers, traditions and images of the region, strong or weak social networks in the home region, lifestyles and migration cultures. So the challenge for planning in shrinking and stagnating regions is the crucial role of work places and job opportunities for women and men according to their qualifications and offering possibilities to earn a living in order to stay in the region. Secondly this is the adaptation and maintenance of public and private infrastructures of everyday life needed for a changing and ageing population; change regarding a raising participation of women in the labour market as well as of people above the age of 65 . The infrastructures for everyday life are a big challenge for communities, as public budgets are constantly reduced and the loss of population is accompanied by a loss of financial means as well.

Furthermore, we highlight the importance of participation and good governance, which includes the possibility of women and men of all ages and backgrounds to shape the future of

\footnotetext{
${ }^{6}$ SEMIGRA stands for Selected Migration and Unbalanced Sex Ratio in Rural Regions; Leadstakeholder was the Ministry of Regional Development and Transport of the Federal State Saxony Anhalt.
} 
their communities and regions (Hudson \& Rönnblom 2008) and to participate in political decisions. In fact, the gender imbalance in decision making bodies like local councils, advisory boards or interest groups in most of the European countries is strong. For the case regions Bavaria and Austria, there is evidence, that in remote rural communities, the dominance of male decision makers has even increased. (Magel et al 2011, Aufhauser 2005).

In our view, the results and recommendations of the SEMIGRA project confirm the relevance of these topics for gender planning addressing female emigration. The SEMIGRA project proposes six fields of action: Work and labour market, social infrastructure, accessibility and education are further fields of action, which is our gender planning approach for "Infrastructure for everyday life'. Finally, the field of action of SEMIGRA called 'place and attachement' includes active citizenship, participation and further attractive (leisure) infrastructure services (SEMIGRA 2013a, 16).

\subsection{Work: paid work, care work, voluntary work}

Talking about "work" with a gender lens means not only to put in focus paid work as worker or entrepreneur to earn ones living, but also to put in focus care and family work as well as voluntary work in NGOs or in local decision making bodies.

Although since the sixties the societal roles have changed, in many European countries the distribution of domestic tasks between women and men is still unbalanced: Mothers with young children have much less free time and their share of unpaid work in care economy (household, child care) is much bigger than that of men. While - in average - women in Land Salzburg $^{7}-$ work $48 \mathrm{~h}$ per week against 36 hours of men, only 18.1 hours $(=37 \%$ of the weekly working time) are paid work against 29.7 hours $(=82 \%)$ of men's weekly working time. While women work22 hours per week for their households and 9 hours for child care, men only spend 4 hours per for household chores and $2.5 \mathrm{~h}$ for child care (Statistik Austria 2004 - Mikrozensus).

\begin{tabular}{|r|l|l|l|l|}
\hline & $\begin{array}{l}\text { weekly } \\
\text { working hours }\end{array}$ & $\begin{array}{l}\text { there from } \\
\text { household }\end{array}$ & $\begin{array}{l}\text { there from } \\
\text { child care }\end{array}$ & $\begin{array}{l}\text { there from paid } \\
\text { work }\end{array}$ \\
\hline Women & $48 \mathrm{~h}$ & $21.8 \mathrm{~h}(44.8 \%)$ & $8.9 \mathrm{~h}(18.2 \%)$ & $18.1(37.0 \%)$ \\
\hline Men & $36 \mathrm{~h}$ & $4.0 \mathrm{~h}(11.0 \%)$ & $2.5 \mathrm{~h}(7.0 \%)$ & $29.7 \mathrm{~h}(82.0 \%)$ \\
\hline
\end{tabular}

Tab 2. Gendered distribution of paid and unpaid work- Salzburg 2004 (Statistik Austria).

These gendered distribution of unpaid care work in weekly working hours can still be observed in all European countries in spite of long time efforts in combating discrimination and in promoting equal opportunities for women and men. According to the Quality of Life Survey in 2012, on EU-average a working man spends 35 hours weekly for child care, cooking or housework and caring for elderly or disabled, a working woman spends 51 hours for unpaid work, which is more than a full time job (Eurofund 2012, 68).

From these social roles of gendered distribution of care work not only result strong differences in income - the gender pay gap - but also very different time-space patterns and daily routines for shopping, medical care, walks to the children's playground etc. Lack of child care infrastructures which causes limited access to labour market and results in low paid part time work or no paid work at all in rural areas etc. hits strongly the living conditions of women and by this - can enhance selective emigration of women (Buchinger et. al 2010).

\section{Gender differences and spatial living conditions between rural and urban areas}

A study on gender (in-)equality in rural Bavaria- which was initiated by the Bavarian State Ministry for Labour, Family and Women - tried to analyse regional differences between women and men to map inequalities between women and men in the rural areas of Bavaria. One

\footnotetext{
7 The author considers Land Salzburg as "rural area" as there are 534.000 inhabitants in 119 communities, thereof 148.000 in city of Salzburg, the next biggest city only has 20.000 inhabitants.
} 
important element of the project was to bring into discussion the unequal distribution of care and family work and to show regional differences between metropolitan areas and rural areas and to provide a set of basic indicators and a set of recommendations for action for communities and districts in rural Bavaria. ${ }^{8}$. Referring to the gendered planning cycle (Fig 4) it covers the steps of initiation, project design, public participation, analysis, objectives and model for action with measures.

One result of the study was, that there are strong differences between the metropolitan areas of Greater Munich-Augsburg and Greater Nürnberg - and the most peripheral rural areas of Bavaria: Within a set of 17 indicators there are significant differences in 15 indicators between the 2 types of regions; the differences are strong especially with indicators linked to traditional gender roles. There is a big difference in political representation in village and city councils: Only one out of five councillors is a women while in metropolitan areas the ratio is one out of three (Magel et al 2011, 17). Another traditional pattern can be observed in child care: Parental leave is less shared between women and men than in Metropolitan Bavaria, so more fathers stay with their child for just 1 - 2 months, which is the minimum to get the full parental money, while more women stay for more than 8 months ${ }^{9}$.

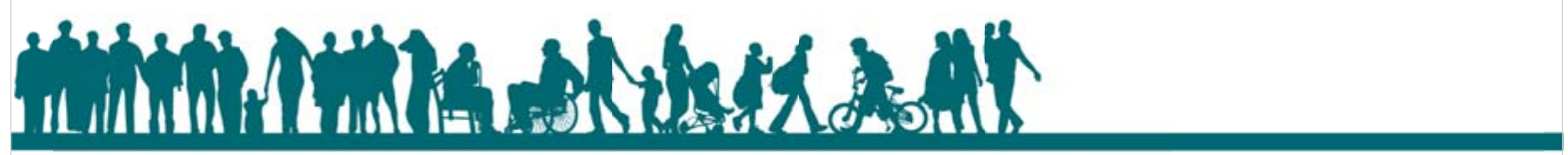

\section{... \% of women/men, who have got parental money in 2008}

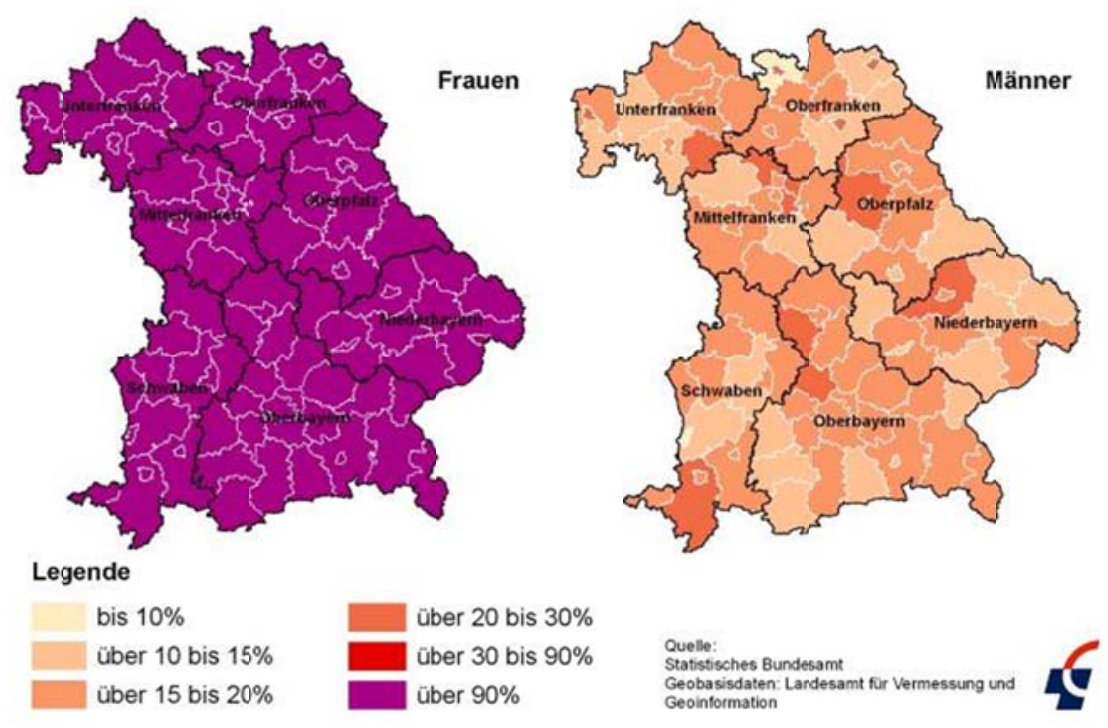

planwind.at

planning management.research

Fig 5. Gendered distribution of child-care work (first 12 months of children) between women (map on the left side) and men (right side) in Bavarian districts. The map shows the percentage of women/men of all women/men aged 15 - 65 being in parental leave for more than 8 months (über = above, bis=til). (Magel et al 2011)

\footnotetext{
${ }^{8}$ An ESF-funded project. Warum Frauen nicht arbeiten können und Männer das Geld verdienen. Mehr Chancengerechtigkeit im ländlichen Raum Bayerns durch Vereinbarkeit von Familienarbeit, Erwerbsarbeit und Freiwilligenarbeit. "Why women cannot work and men earn the money. More equality justice in rural Bavaria through balanced care work, paid work and voluntary work" (translation by the author). The author was involved as gender expert for the Grontmij Gmbh Munich in both stages, in project design and in implementation.

${ }^{9}$ Parental money up to $67 \%$ of the average salary of the last 12 months (max. $1.800 €$ min $300 €$ ) has been paid to parents since 2008 for max. 10 months for 1 parent (mostly the mother) plus another month if the second partner (mostly the father) takes parental leave for minimum one month.
} 


\subsection{Infrastructures for everyday life}

Female participation in the labour market depends very much on the living area. While in rural Bavaria only 49.9 of women but $63 \%$ of men have access to paid work (difference of 13 'inequality' percentage points), in metropolitan Bavaria the difference is 'only' 10 percentage points between women and men (Magelj et al 2011).

Compared to Salzburg the differences between women and men e.g. in the most rural district Tamsweg is $9.5 \%$ - 78.8 for men and $68.3 \%$ for women; the participation rate of women is the lowest rate of State of Salzburg (Demochange 2011a, 48).

The European Union has pointed out the link between provision of child care facilities and the access to the labour market. So the EU-members have set as goal in the Barcelona presidency conclusions in 2002 that till 2010 33\% of all children aged below 3 years and $90 \%$ of all children aged $3-6$ years shall have a place in a child care facility ${ }^{10}$.

A closer look at a Bavarian rural district - the Oberallgäu and the city of Kempten (kreisfreie Stadt) - shows the regional differences in the offer of child care infrastructure: Officially, each child has the right to a place in a child care facility from 8 to 12 o'clock. This is not even enough for a half-day job! So the map on the right side in Figure 7 shows the number of children in day care facilities from 8 a.m. till 4 p.m. with lunch service for children below the age of 15 years. In 13 communities there is no offer at all, only in small market towns and in the bigger district centre, the city of Kempten, the offer of child care facilities is good. This leads to the challenge of accessibility and mobility offers in rural areas as public transport offers are sparse and tend to be reduced further.

This has enormous consequences for people with care responsibilities and consequences for all people who depend on public or private transport: Children, elderly people, people without a driving licence and without a car, people with sustainable lifestyle who want to have a low carbon footprint. If the offer of public transport is bad, independent mobility of these children or the elderly without cars is restricted. They depend on private transport and on 'taxi mum' or 'taxi daughter'. This makes care work even more difficult in rural areas.

The map on the left side in Figure 6 shows the quality of bus services on weekdays in the communities of the district of Oberallgäu; it also shows that there are three communities with bad public transport connection. Nowadays, the big challenge for Central Europe is to improve the child care facilities according to the Barcelona targets towards the quality offered in Scandinavia and in France at the same time as to build up a supportive infrastructure for care for the elderly. This is also one condition to reach the European goal for a general rate of $75 \%$ of the European population group aged 20 - 64 which shall participate in the labour market to a broad extent; in Austria the target it 77-78\% (Europe 2020 strategy - agenda for a smart, sustainable and inclusive Europe ${ }^{11}$ ); this means that female participation has to rise as well as the working career has to become longer between the age of 60 and 70 .

\footnotetext{
${ }^{10}$ EU-wide set targets for child care - the so called 'Barcelona Targets' - in the Presidency Conclusions of the BarceIona Council on March 15-16/2002 - online http://ue.eu.int/ueDocs/cms_Data/docs/pressData/en/ec/71025.pdf

${ }^{11}$ Europe 2020 Targets http://ec.europa.eu/europe2020/t5rgets/eu-targets/index_en.htm - accessed on Jan 05,2013
} 


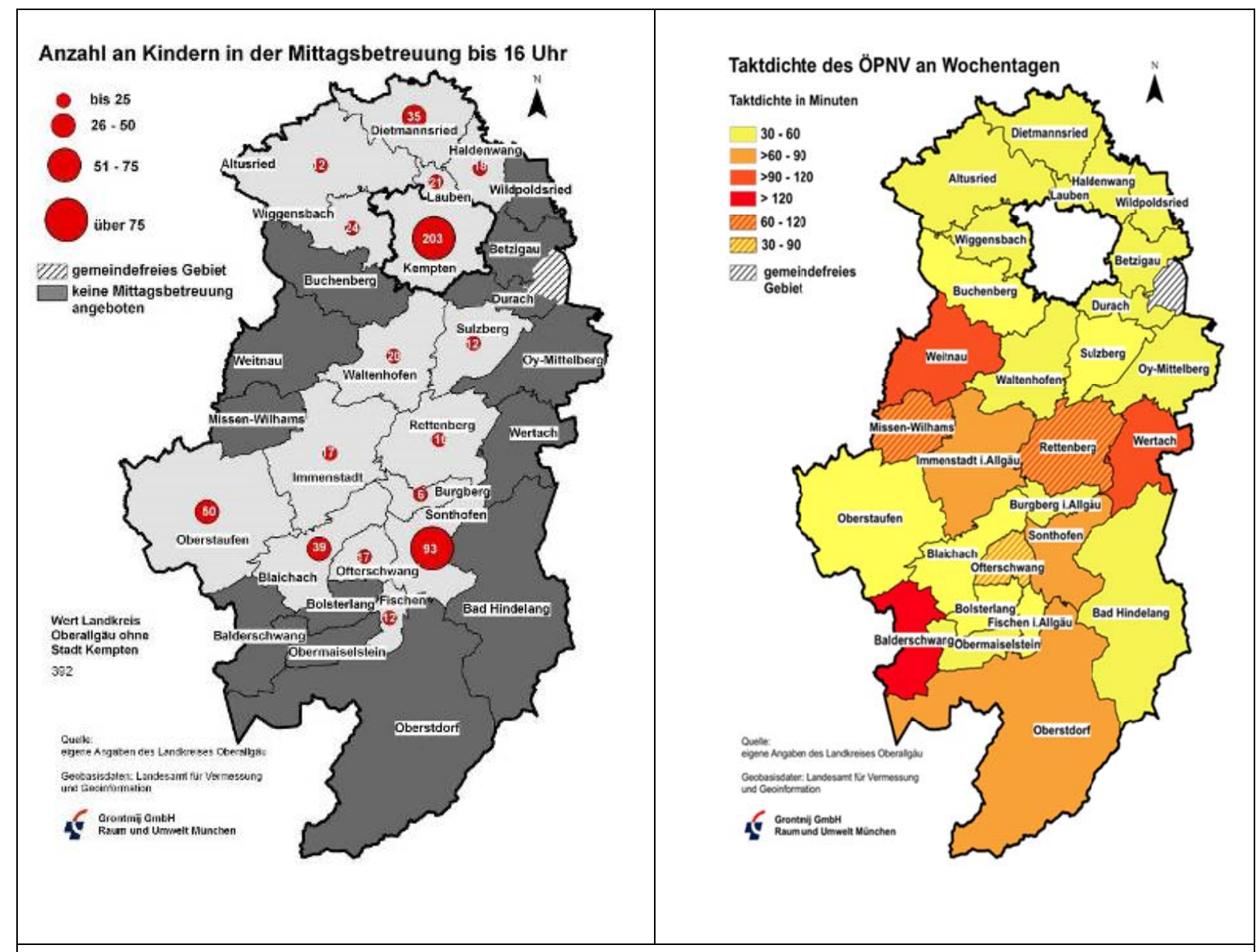

Fig 6. Left: Day care infrastructure with lunch and opening hours till 4 p.m. for children aged 0 - 15 in district Oberallgäu. Size of the circle according to the number of children. 12 communities are without any day care offer (dark grey areas). Right: Bus schedule on weekdays - dark red colors show the frequence less than every 120 minutes (Magel et al 2011)

\subsection{Participation and Governance}

Participation in decision making is one of the key revendications of feminist activists and is to be found in all gender planning approaches (Fainstein 2005, 2009, Hudson \& Rönnblom 2010, Roberts 2006, 2013, Zibell 2006) as well as in mainstream planning (Healey 2006). A participatory approach to gender planning would include equal participation of women and men and transparency in decision making (Zibell 2006: 1).

But participation and governance is not only a basic democratic value for citizens based in the fundamental citizen rights, but also a key factor for local and regional cohesion and for local and regional planning and development. There is clear evidence from several migration studies that the sense of belonging and the attachment to a place depends on the level of how strong is the involvement in local association and policy making (SEMIGRA 2013a, Demochange 2013). One of the main reasons to stay in the small rural community is the possibility to shape the future and the network of people (statement from a female vice-mayor of a small community in Salzburg, www.demochange.at). One of the key strategies of the SEMIGRA projects to fight against female emigration is to stimulate active citizenship to improve place attachment and the internal and external image. 


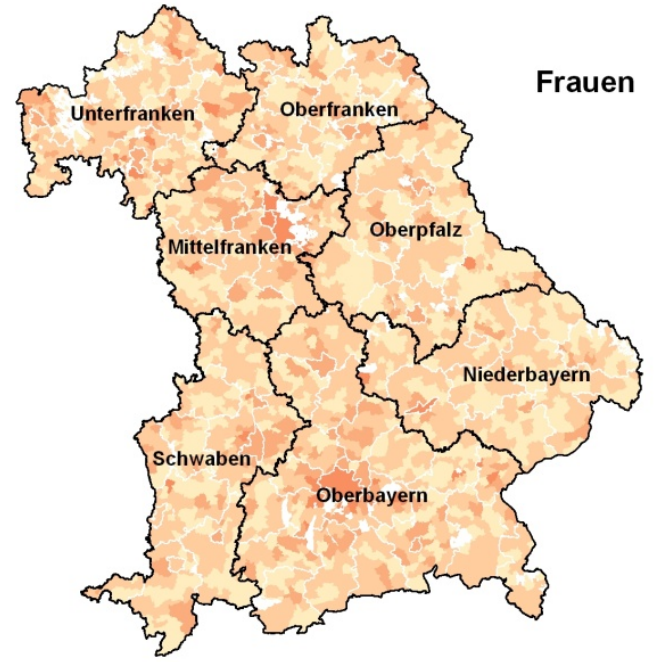

Legende bis $12,5 \%$

über 12,5 bis $25 \%$

über 25 bis $37,5 \%$

über 37,5 bis $50 \%$

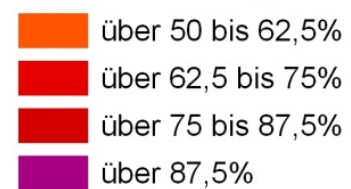

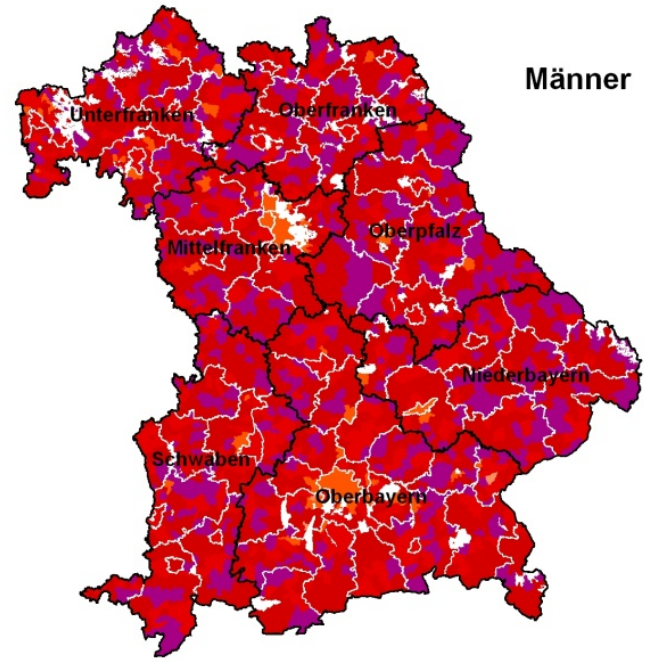

Quelle:

Bayerisches Landesam

für Statistik und

Datenverarbeitung

Geobasisdaten:

Landesamt für Vermessun

und Geoinformation

Fig 7. Participation of women/men in local community councils in 2008. The map shows the percentage of female/ male community councellors (über = above, bis=till). (Magel et al 2011)

Same situation in Austria: Only 5\% of the mayors in Austria are women (Oedl-Wieser et al. 2012; NB: data do not distinguish between rural and urban communities). According to them, this gender-imbalance persists as members of intermediate bodies e.g. LEADER-groups or regional development and planning boards are mostly mayors and other leaders of special interest groups. Only the Leader regions which started to work after 2007 have more women in their boards; they had to meet a quota of $30 \%$.

\subsection{Evidence on gender differenciated migration flows and unbalanced age-groups - the challenge}

As demonstrated above, rural areas in Austria and Bavaria face the challenge of attractiveness and lack of supportive infrastructure for care economy. This is one reason out of many other reasons (like job opportunities) why emigration from shrinking areas is selective: 'selective' means young women with good qualification are leaving a region to a higher percentage than men.

This selected emigration of women can be observed in rural areas in the Alps and they will be stronger in the future: The projections of the demographic trends per age cohorts and sex in nine model regions of the Demochange project ${ }^{12}$ in Austria, Bavaria, Switzerland, Slovenia and Italy show a loss of young women aged 15-49 in 8 out of the 9 regions: $-29 \%$ in Upper Gorenjska in Slovenia between 2008 and 2030, -13 to -14.5\% in Oberallgäu (Germany) in Salzburg's rural south (Pongau, Lungau, Pinzgau, Austria) and in Škofja Loka Hills (Slovenia); only minus $10-12 \%$ in Nidwalden, Switzerland and in Aosta Valley (Italy), and almost no change in South Tyrol Valle d'Isarco/ Eisacktal. (Italy) (Demochange 2011a, 19). The projection from 2008 to 2032 for the Alpine rural region Lungau/ Tamsweg expect 48 women to 52 men, in some communities 40 women to 60 men and a rise of the average age from 39 in 2008 to 47 in 2032 (Land Salzburg Statistik).

${ }^{12}$ Demochange 2011a 


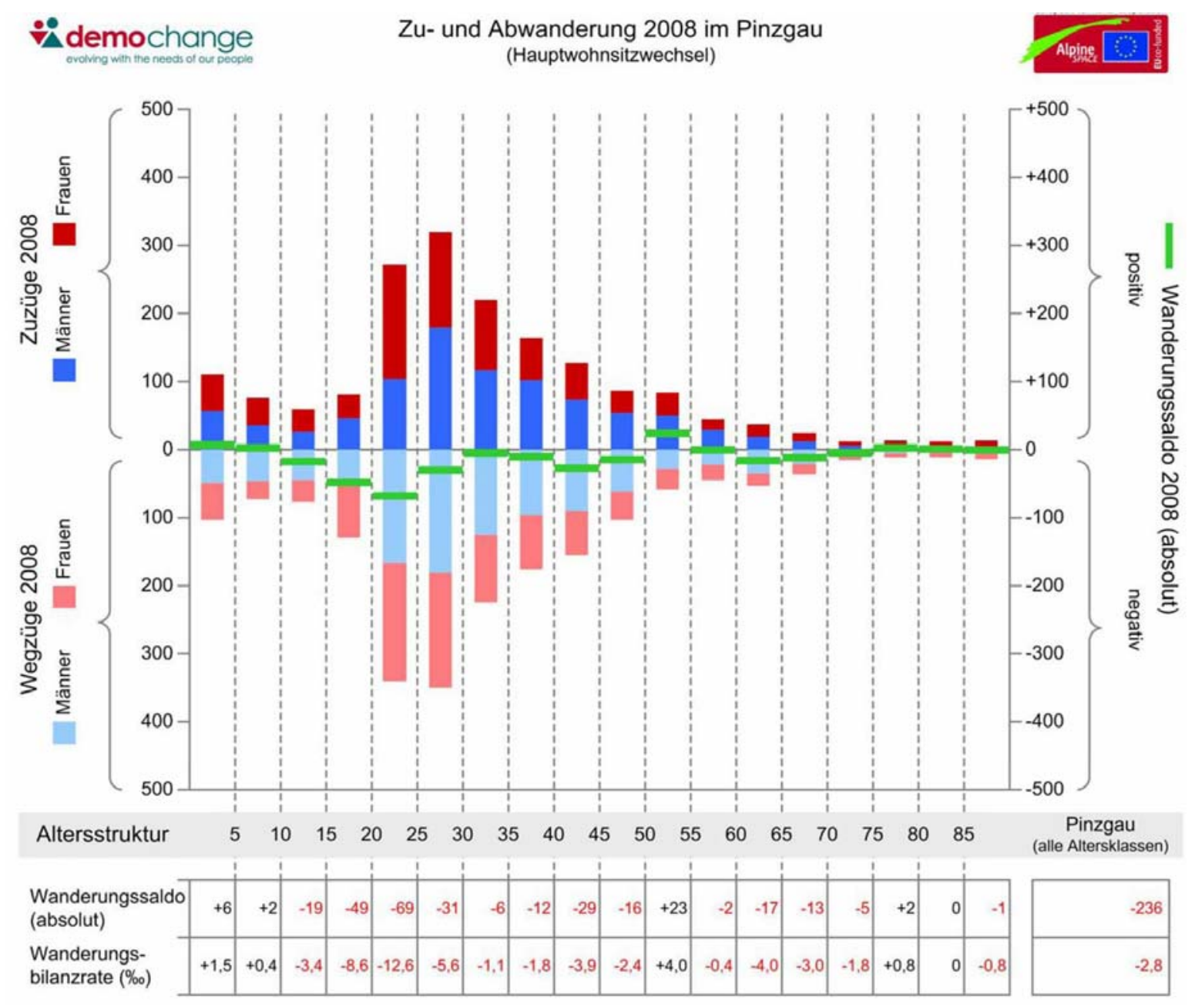

Fig 8. In- and out-migration 2008 into district of Pinzgau / Zell am See, Austria according to age-cohorts (groups of 5) and sex: Above in-migration, below out-migration, red - women, blue - men, green - balance of in- and outmigration (Demochange 2011).

A close-up of migration flows in a rural district from the year 2008 per age cohorts and sex shows (see Figure 7) a very complex picture with very different migration movements in age groups and per sex: The example of the biggest district of Salzburg, the district of Zell am See I Pinzgau shows a strong dynamic in different age groups and differences between women and men. While the average migration flow of the district was minus $2.8 \%$ in one year $(-236$ people in 2008), the balance in 3 age groups (0-5, 5-10 and 50-55) is positive. The strongest migration movements can be observed in the age groups 20 and 35: Out- and in-migration of women and men, e.g. for marriage, emigration of women and men for university and other higher education. Female emigration is higher in all age groups between 20 and 45 than in-migration, but equal or less strong in numbers than male emigration.

Compared to other rural regions, the Salzburg situation is not dramatic; for example in most of the rural shrinking districts of Eastern Germany e.g. Mecklenburg-Vorpommern, the female emigration is really strong. Some rural areas have lost more than $20 \%$ of their population in total from 1982-2008 (e.g. the very peripheral rural district Ücker-Randow -25\%). In this region the selected emigration of young women results in a relation of 137 men to 100 women (Mecklenburg-Vorpommern Statistisches Amt 2009). In urban agglomerations and metropolitan areas, but also in rural areas with a strong service sector in tourism - on the other hand women are the majority of the population (Berlin Institut 2009, 20).

This diagnosis is confirmed by the SEMIGRA project. It turned out that regions characterized by a massive deficit of women in all considered age groups are predominantly rural and are mainly located in Eastern Germany (SEMIGRA 2013a, 8). This means that the shortage of women in the age groups 20-34 is related to the German Reunification. 


\section{Experiences from Applied Gender Planning Methods in Rural Regions}

Chapter 3 presents three concrete examples from Austria and Bavaria by looking closer at the applied gender planning methods, tools and strategies in the above mentioned three key issues, namely work, infrastructures for everyday life and participation.

\subsection{Planning including everyday life - regional level - spatial strategy for housing and work}

In 2004, the spatial planning department of State of Salzburg, together with the Office for Women's Affairs and Gender Equality decided to revise the 1995 Spatial Strategy for the Greater Salzburg Region for housing areas and industrial sites by integrating a gender aware approach. The spatial strategy sets the framework for local spatial development concepts, land-use plans and infrastructure planning. This project was one of 35 partner projects within the European project called 'GenderAlp! Spatial Development for Women and Men ${ }^{13}$. Although City of Salzburg is the capital of the federal state of Salzburg, we consider the whole region as "rural" with a big number of communities and villages and a relatively small city (148.000 inhabitants in City of Salzburg) ${ }^{14}$.

The planning process followed a typical planning cycle and a gender mainstreaming strategy for important steps. Work started with an evaluation of the goals and measures and a regional data analysis. Starting point was a regional analysis broken down to sex, the spatial structures and the infrastructure (public transport infrastructure, child care facilities, elementary schools and services and facilities for the daily needs) were mapped for showing different spatial qualities and the potential of existing and future housing and working areas (Wankiewicz \& Schrenk 2004). These qualities have gained importance in the strategic objectives and measures and in the Gender Impact assessment. An inventory of practices and tools in gendered spatial planning on all scales - from housing blocks up to spatial strategies at federal state level (Zibell 2006) - opened up the discussion about the state of the art in gender planning practice and the need for improvement. Following the draft concept of the new spatial strategy for housing and working, a gender impact assessment of these objectives and measures made suggestions for more equality-oriented planning. After considering the different interests, the Spatial Strategy came into force in 2009.

The project has demonstrated that gender mainstreaming in planning as a top-down approach is a useful strategy for improving spatial planning practice. Four of the spatial strategies and binding regulations are strongly linked to gender planning issues (Land Salzburg 2009: 6-7). E.g. the polycentric spatial settlement strategy prescribes that new housing areas should be strongly oriented towards well-equipped regional centres with good public transport, living and working in a region with short travel distances, everyday life needs are reflected in this concept, which requires quality and accessibility of public and private services and concentration and increased density of future settlements along public transportation nodes and axes. This strategy provides independent mobility for all people without cars, supports those who are carers and keeps access to workplaces and to living places flexible and adaptable. Allocation of working place areas close to regional centres and within centres. Work and family life are reconciled by providing an accessible basic infrastructure as an integrated part of the location development.

There is, however, a need for a bottom-up approach for opening the process and for integrating users and different interest groups into decision-making. Participation was limited to the classic

\footnotetext{
13 'GenderAlp! Spatial Development for Women and Men' was launched by Land Salzburg to provide new knowledge and practical tools on gender planning, gender mainstreaming in administration and in public subsidies (gender budgeting). The focus was laid on sensitising and on developing practical instruments for user oriented and "gender" planning projects in these structural policy fields, where high investments are decided. The budget was co-financed half by the 12 project partners from Austria, Germany, Italy, Slovenia and France, half by the European Fund for Regional development (ERDF) within the program 'Alpine Space'. (01/2005 - 12/2007) Project website www.genderalp.at

14 Other partner projects took place in big urban agglomerations like Genova (800.000 inhabitants) and Munich (1,3 Mio inhabitants)
} 
stakeholder management. No NGO was involved, and there was no gender balance within the process - all members of the working group except the project manager and two experts were men.

After two years of implementation it is too early to evaluate the impact of the new strategy. The long-lasting effects of the project include the fact that 'gender planning' as a concept still raises resistance, but the key planning strategies relating to everyday life, to domestic facilities and to a region with short travel distances with good public transport have gained in strength and acceptance within the planning community.

\subsection{Planning infrastructures for everyday life - local level - Demochange pilot action}

The public participation project on local infrastructures in two Austrian communities - Fusch and Lend with strong population loss in the last decades has revealed that women can be easily involved into local participation, if they are invited. This project was part of the Alpine Space Demochange project and has been initiated by the two mayors of the communities. 'Gender' has not been on the headers of the process, but integrated into analysis, invitation of focus group members and citizen forums. Data analysis, focus group interviews, a survey addressed to all households and a mobile exhibition to sensitize on demographic change dynamics have been done. Concerning emigration, a detailed survey has shown that most of the emigrants have left to settle in the neighbouring communities.

Key findings of the participation process were that the satisfaction of women and men with the infrastructures of everyday life have been assessed positively as people include into their assessment also the infrastructures of the neighbouring communities. Surprisingly - with exception of a local shop - the desired infrastructures were socially defined, means better relations between generations, more meetings and exchange between the local people. Public debate has started on the future of civic engagement at local level. (Demochange 2013, $38 \mathrm{ff}$ and www.demochange.at)

\subsection{Assessment of local community policies: gender (planning) checklist - case of Fusch, Salzburg}

As Mieke Verloo proposed in her intervention on the Vienna conference on 10 years of gender mainstreaming in the City of Vienna, people should think about themselves, their practices and their institution as an 'ongoing gender inequality constructing organisation' (2 Oct., 2012). To avoid discrimination and to assess decisions for municipal councils, a checklist has been developed for Salzburg community level within the Demochange project.

Starting point was a change in Austrian legislation for public authorities. Since 2012 all communities (and other public authorities) have had the duty to assess the impact of their decisions on women and men according to Art. 3(3) and Art. 51 (8) B-VG of the Federal Constitution Law. As there is a lack of knowledge and skills in practical implementation of gender mainstreaming from simple employees up to top-executives, a project was conceived to develop and test an easy to learn tool and to transfer this tool to other communities.

It is important to mention that local governments have the legal power for spatial planning, land use planning and building permits, for housing and transportation issues, for child-care and health-care and for investments into social and leisure infrastructure. This checklist should help to assess the impact of future decisions of a community on women and men, girls and boys and additionally different groups in a standardized way. The checklist should be easy to use without intense research and knowledge. This checklist has been tested successfully in the community of Fusch an der Glocknerstraße, but has not been transferred to other communities yet (www.demochange.org/pilotaktionen)

The project has shown a high sensibility and knowledge of policy makers about all aspects of changing lifestyles, changes in living conditions due to car orientation and loss of infrastructure and on the importance of voluntary - unpaid work. On the other hand, the project has shown a persisting strong resistance against everything which is linked to 'gender equality' or 'gender mainstreaming', regardless as to whether it is at community at regional, federal or European 
level, and regardless of the players being men or women. Some reasons may be that gender equality, equity and gender justice touches personal values and identities and challenges the personal and one's own concept of 'male-female' and of gendered roles. This confrontation causes hostility and rejection. Hopefully in future skills and knowledge on gender mainstreaming and equality policy tools will support the application of this checklist.

\section{Conclusions}

Gender planning provides a wide range of field tested and appropriate concepts and methods which can easily be transferred to demographic change issues. Looking at demographic change impact on space and planning by integrating gender issues means recognizing a growing diversity of time-space patterns, a growing diversity of family models and living arrangements. This means furthermore looking very closely at users' needs and integrating everyday life and daily routines and the spatial requirements of the care economy like new forms of housing, social infrastructure and services into spatial concepts and organisations. Planners will need to revise their concepts, goals, measures and practices by recognizing the 'diversity of users' and the diversity of time-space uses.

The gender planning concept places women and men and their relationship to each other in focus, but extends this concept to all other (minority) groups and special interest groups in society, which suffer stereotyping, discrimination and have no voice in planning process; so it can easily applied for demographic change dynamics. A useful method is to evaluate spatial structures according to their usability in everyday life for women and men with consideration of age, different life conditions, cultural and social background, lifecycle and family situation. By doing this, it has to be in mind that gender planning has a transformative potential for power relations between women and men and their gender roles. This potential can only be used, if basic social conditions, norms, values and underlying planning concepts and family concepts are challenged and revised; notably the revised concept of housing and (care) work, and an extended concept of planning by involving women and men, girls and boys into local and regional development.

Analysis have shown distinctive geographical, socio-spatial and cultural differences between metropolitan areas and rural areas, where reconciliation of paid work and of unpaid family/ care work is much more difficult and where the gendered distribution of this work is much more imbalanced.

Gender planning tools and practice can help to understand and face the challenge of selected migration flows from shrinking regions. Selective means young women with better qualifications move towards urban centres, which attract them with a broad range of job offers and a good supportive infrastructure for care tasks. Infrastructure, which makes full time jobs accessible for women and men, single parents or people who care for their old parents.

As for all planning procedures, there is a strong need for critical revision of decision making and planning processes, by assuring a broad participatory approach - which is challenging in traditionally oriented rural areas. There is need for better governance enhancing the participation of women in local and regional decision making in order, not only for enhancing active citizenship but also for increasing the attachment to the local community and to prevent emigration.

15 years after the Treaty of Amsterdam, the investigation of gender planning concepts, instruments and experiences and strategies has confirmed that gender planning can contribute a lot to tackle the impact of demographic change.

\section{Acknowledgements}

The paper is an outcome of the scientific session of the final conference of the Alpine Space project DEMOCHANGE - demographic change in the Alps. Adaptation strategies in Spatial Planning and Regional development. This session was initiated and supported by the Austrian Scientific Partner University of Salzburg, Department of Geography and Geology, Social Geography Research Group (www.socialgeography.at). 
[1] Aufhauser, E. (2005). Unternehmerinnen \& Unternehmen in der Innovationsregion Süd Ost. [Project Ginnova]. Universität Wien.

[2] Burgess, G. (2008). Planning and the Gender Equality Duty- why does gender matter? In: People, Place and Policy Online 2(3), 112-121.

[3] Buchinger, B., Huber, P., Lutz, H., Mayrhuber, C. \& Schratzenstaller, M. (2010). Salzburger Leitbild für Chancengleichheit von Frauen und Männern. Wien: Österreichisches Institut für Wirtschaftsforschung.

[4] De Certeau, M. (1984). The Practice of Everyday Life. Berkely: University of Califonia Press.

[5] CEC (2010). Charter of the Fundamental Rights of the European Union. Official Journal of the European Union C 83, 391-403.

[6] CEC (2006a). Council Decision of 6 October 2006 on Community strategic guidelines on cohesion. Official Journal of the European Union L291, 11-32.

[7] Cortolezis, H. (2010). Steht Regionalentwicklung drauf, muss Gender Mainstreaming rein. Raum vol. 77, 26-29.

[8] Damyanovic, D. (2007). Landschaftsplanung als Qualitätssicherung zur Umsetzung der Strategie des Gender Mainstreaming. Theoretische und methodische Konzepte eines gendergerechten Planungsprozesses als Bestandteil des Örtlichen Entwicklungskonzeptes dargestellt an der Fallstudie Tröplach/Stadtgemeinde Hermargor/Pressegger See (Kärnten). Wien: Guthmann-Peterson.

[9] Demochange (2013). Der demographische Wandel. Herausforderungen für Raumplanung und Regionalentwicklung. Land Salzburg.

[10] Demochange (2011a). Demographic Change in Model Regions Pongau-Pinzgau-Lungau. [Short Regional Report]. Land Salzburg/Universität Salzburg.

[11] Demochange (2011b). Porträt der Salzburger Modellregion Pongau-Pinzgau-Lungau. Land Salzburg/Universität Salzburg.

[12] Dollinger, F., Spitzer, W., Prinz, T. \& Wankiewicz, H. (2010). Raumplanung als Alltagsmanagement für ALLE? Herausforderungen des demographischen Wandels Werkstattbericht Demochange. In Schrenk, M., Popovich, V. V., Zeile, P, eds.: Real Corp Proceedings (pp. 599-608). Wien.

[13] Egerö, B. (2012). Four decades of Swedish cohousing - what chances of a real take-off? In Proceedings of the conference, Self-managed co-housing: born out of needs or new form of life? (pp. 66-80): Tours: CNRS.

[14] Fainstein, S. (2009). Spatial Justice and Planning. Journal on Spatial Justice and Planning $1(1), 58-77$.

[15] Fainstein, S. \& Servon, L. (2005). Gender and planning: A Reader. Piscataway (NJ): Rutgers University Press.

[16] Greed, C. (1994). Women and Planning. London: Taylor and Francis.

[17] Magel, H., et al. (2011), Warum Frauen nicht arbeiten können und Männer das Geld verdienen. München: Grontmij.

[18] Häberli, R., Lüscher, C., Praplan Chastonay, B. \& Wyss, C. (1991). Boden-Kultur. Vorschläge für eine haushälterische Nutzung des Bodens in der Schweiz. Zurich: Verlag der Fachvereine.

[19] Healey, P. (1997). Collaborative planning: Shaping Places in Fragmented Societies. London. UBC Press. 
[20] Horelli, L. (2013). Gender Sensitive E-Planning for Sustaining Everyday Life. In Sanchez de Madariaga, I. \& Roberts, M., eds, Fair Shared Cities. The Impact of Gender Planning in Europe (pp. 231-248). Farnham: Ashgate.

[21] Horelli, L., (2010). Sustaining Everyday Life through Psychological Presence, Time, and Space. In: Karlsson, K. \& Ellegård, K., eds., Proceedings of the Sustaining Everyday Life Conference. Issue 38. Linköping University.

[22] Horelli, L. (2009). Gender-Sensitive Community Informatics for Sustaining Everyday Life. Paper presented for the Madrid EURA-Conference on "City futures in a Globalised World" Madrid 04.-06.06.2009.

[23] Hudson, C. \& Rönnblom, M. (2008). The Woman-Made City - Feminist Utopia or Practical Possibility? In Denèfle S., ed., Utopies féministes et expérimentations urbaines (pp. 73-90). PU Rennes.

[24] Kail, E. \& Irschek, E. (2010). Fair shared city: Gender Mainstreaming planning strategy in Vienna In Gender and Urban policies, strategies for gender mainstreaming and local governance (pp. 43-66). City of Seoul.

[25] Karlsson, K. \& Ellegård, K., eds. (2009). Proceedings of the Sustaining Everyday Life Conference. Issue 38. Linköping University.

[26] Labit, A. (2012). Self-managed cohousing within the context of an ageing population: some experiences in France, Germany and Sweden. In Proceedings of the conference ,Selfmanaged co-housing: born out of needs or new form of life?' (pp. 66-80): Tours: CNRS.

[27] Land Salzburg (2009). Sachprogramm. Standortentwicklung für Wohnen und Arbeiten im Salzburger Zentralraum. Land Salzburg.

[28] Land Salzburg and Partners, eds. (2007a). GenderAlp! Spatial development for women and men. [Final publication]. Salzburg.

[29] Land Salzburg, ed. (2007b). Living and working in Salzburg for women and men. Requirement oriented spatial planning. GenderAlp! best practice documentation. Retrieved from http://www.genderalp.com/IMG/pdf/82_Salzburg_planning_May_07-pr-eng.pdf, accessed: 5/10/2013.

[30] Land Niederösterreich, ed., (2007). GenderAlp! Equality in in Lower Austrian Business parks. [Short report: Results and Recommendations]. St. Pölten: Land Niederösterreich..

[31] Larsson, A. (2006). From equal opportunities to gender awareness in spatial planning. Town Planning Review 77(5), 509-530.

[32] Lefebvre, H. (1991). The production of Space. Oxford. Blackwell.

[33] Löw, M. (2001). Raumsoziologie. Frankfurt am Main: Suhrkamp.

[34] Massey, D. (1994). Space, Place and Gender. Minneapolis: University of Minnesota Press.

[35] Oedl-Wieser, T., Gmeiner, P. \& Machold, I. (2012). Politische Mitbestimmung von Frauen in ländlichen Regionen Österreichs, Fact Sheet Nr. 3, Wien: Bundesanstalt für Bergbauernfragen.

[36] Roberts, M. (2013). Introduction: Concepts, Themes and Issues in a Gendered Approach to Planning. In Sanchez de Madariaga, I. \& Roberts, M., eds, Fair Shared Cities. The Impact of Gender Planning in Europe (pp. 1-20). Farnham: Ashgate.

[37] Roberts, M. (2006). A place for citizenship? Women, Urban Design and Neighbourhood planning. In Buckingham, S. \& Lievesley, G., eds., In the Hands of Women: Paradigms of Citizenship (pp. 95-126). Manchester University Press.

[38] RTPI (Royal Town Planning Institute 2007). Gender and Spatial Planning. RTPI Good practice note 7 . Online retrieved from http://www.rtpi.org.uk/knowledge/publications/goodpractice-notes/gpn-7-gender-and-spatial-planning/ - accessed 26/10/2012. 
[39] SEMIGRA_a (2013). Selected Migration and Ubalanced Sex Ratio in Rural Regions. ESPON Targeted Analysis 2013/2/15. [Final Report] V. 30/06/12. Leipzig: Leibniz Institute for Regional Geography.

[40] SEMIGRA_b (2013). Case Study Report Sachsen-Anhalt. [Annex 2 A / Version 28 June 2012]. Leipzig: Leibniz Institut für Regional Geography.

[41] Soja, E. W. (2009). The city and spatial justice. Journal on Spatial Justice and Planning. 1(1), 31-38.

[42] Statistik Mecklenburg-Vorpommern (2012). Der demografische Wandel in MecklenburgVorpommern - Veränderung der Altersstruktur, demografische Alterung und Schrumpfung von 1982 bis 2007 Retrieved from: http://www.statistikmv.de/cms2/STAM_prod/STAM/_downloads/Bevoelkerung/2-Altersstruktur.pdf, accessed: 12/01/2012.

[43] Theorizing and Practizing Gender Sensitive Planning in European Discourse (2013). Leibniz Universität Hannover.

[44] Tummers, L. (2013). Spatial planning at work: a gendered perspective form the Netherlands. In Sanchez de Madariaga, I. \& Roberts, M., eds, Fair Shared Cities. The Impact of Gender Planning in Europe (pp. 131-154). Farnham: Ashgate.

[45] Tummers, L. (2010). To the heart of planning: is the hardware of spatial planning open to feminist alternatives? In Ernst W., ed., Geschlecht und Innovation. Gender Mainstreaming im Techno-Wissenschaftsbetrieb. Internationale Genderforschung in Niedersachsen (pp.117-136). Berlin: LIT-Verlag.

[46] Tummers, L. \& Wankiewicz, H. (2009). Beyond the 'women friendly-city'. Paper presented for the AESOP YA-conference "Planning as rear view mirror or Crystal Ball? - Diversities of Planning Cultures, Traditions Identities" in Vienna 12.02.2009.

[47] Wankiewicz, H. (2013). European regional development programmes for cities and regions: Driving forces for gender planning? In Sanchez de Madariaga, I. \& Roberts, M., eds, Fair Shared Cities. The Impact of Gender Planning in Europe (pp. 131-154). Farnham: Ashgate.

[48] Wankiewicz, H., (2009). Are we really planning for people's needs? Regions Magazine 274 (Suppl. 1,: 9-11). Doi: 10.1080/13673882.2009.1053.

[49] Wankiewicz, H., \& Schrenk, M., (2004). Raumanalyse Salzburger Zentralraum. Retrieved from http://planwind.at/publikationen/sp_zentralraum-endbericht.pdf. Accessed: 25/10/2012

[50] Wotha, B. (2000). Gender Planning und Verwaltungshandeln. Umsetzung von Genderbelangen in räumliche Planung - unter Berücksichtigung von Verwaltungsmodernisierung und neuerer Tendenzen im Planungsbereich. Kiel: Kieler Arbeitspapiere zur Landeskunde und Raumordnung.

[51] Zibell, B. (2006). Gender practice and criteria in Spatial Planning. GenderAlp! Salzburg Project. Short Version. Salzburg.

[52] ZBG Zweckverband Großraum Braunschweig/ Universität Hannover (eds., 2005). Good Practices. Praxisbeispiele zum Thema Wohnen und Versorgung' (Good practices in housing and supply). Braunschweig.

DEMOCHANGE project - (en, it, slo, ge) www.demochange.org DEMOCHANGE Salzburg (ge) www.demochange.at

GDUS - European Network on Gender and diversity und urban sustainability GDUS (2012) http://www.rali.boku.ac.at/gdus.html

GenderAlp! Spatial development for women and men project: http://www.genderalp.at/

QUING - Quality in Gender+ Equality Policies - The Quing project: www.quing.eu

SEMIGRA - http://www.espon.eu/main/Menu_Projects/Menu_TargetedAnalyses/semigra.html 